(Received July 25, 1986)

\title{
SOME STUDIES ON THE ACTION OF SOME KETONES ON QUIANA-POLYAMIDE FIBRES
}

\author{
By A. Bendak and Sh. Aggour* \\ (National Research Centre, Textile Research Division, \\ Dokki, Cairo, EGYPT)
}

\begin{abstract}
Pretreatment of Quiana polyamide fabric (Q-PA) with some ketones was performed to induce some structural changes in order to improve fibre dyeability. Isothermal shrinkage rate curves of modified Q-PA were characterized by an induction period. The molecular volume of the interacting ketones/solvents influenced the corresponding energy of diffusion $(\Delta E)$ into the polymer. The difference in $\Delta E$ among the ketones/solvent may be associated with some difference in their binding capacity with the substrate. The dynamic shrinkage increased sharply with increasing temperature of pretreatment. Measurement of iodine sorption by modified polyamide allowed detection of induced structural differences.

Changes in capability of modified polyamide to uptake cationic dyes were noticed. Evaluation of time of half dyeing and specific dyeing rate constant indicated that the pretreatment had more powerful influence in disordering polyamide fibre structure. The rate of dye diffusion in the modified polymer increased with rise of dyeing temperature. The apparent activation energy of diffusion showed the ability of the dye molecules to move within the fibre matrix. Calculation of the dye affinity and heat of dyeing anticipated that more disorder in fine structure due to pretreatment was imparted.
\end{abstract}

\section{INTRODUCTION}

Intensive research work has been devoted to study the affinity of various classes of dyes for textile fibres ${ }^{1-3)}$. Basic dyes affinities to polyamide fibres can be improved by addition of triazine derivatives to the polymer preparation ${ }^{4)}$. The use of some compounds, which may behave as dye carrier, swelling agents and/or plasticizers for the fibres, vis. benzyl alcohol ${ }^{5)}$, sodium benzenesulphonate/acetic acid mixtures ${ }^{6)}$, p-tolyl aldehyde ${ }^{7)}$, o-phenyl-phenol, $\beta$-naphthol ${ }^{8)}$, zinc thiocyanate ${ }^{9)}$ and saccharin ${ }^{10}$ ) were tried as additives to the cationic dyeing baths of polyamide fibres. Treatment of polyamide fibres with nickel or cobalt salts after dyeing with cationic dyes in presence of cyclohexanol improve its light fastness properties ${ }^{11)}$. Aliphatic and aromatic ketones are used in low temperature solvent-assisted dyeing

* Faculty of Engineering, Cairo University. of wool fibres ${ }^{12}$, in producing level shade in paddyeing of synthetic fibres with disperse dyes ${ }^{13)}$, assisting dyeing of aromatic polyamide with cationic dyes in aqueous as well as non-aqueous dyeing baths ${ }^{14,15)}$ and in anionic or premetallised dyeing of Kynol or Novolak fibres and their blends with aromatic polyamide to improve the light fastness of the coloured materials ${ }^{16)}$.

In the present study, the role played by some aromatic ketones as additives for dyeing aromatic polyamide fibres with cationic dyes as well as the kinetics of dyeing are thoroughly investigated.

\section{Experimental}

Materials: Quiana polyamide fabric produced by condensation polymerization of bis (4-aminocyclohexyl)methane and dodecanedioic acid, Austria, plain weave $\left(54.5 \mathrm{~g} / \mathrm{m}^{2}\right)$, melting point $280^{\circ} \mathrm{C}$, density $1.03 \mathrm{~g} / \mathrm{cm}^{3}$, shrinkage in boiling water $4-10 \%$, glass temperature (dry) ca. $190^{\circ} \mathrm{C}$, wet 
ca. $85^{\circ} \mathrm{C}$, was soaped washed thouroughly and air dried. Yarns of the same material were also utilized.

Chemicals: Cyclohexanone, 2-butanone, 3-pentanone, acetophenone, acetone, acetic acid, $\mathrm{N}, \mathrm{N}^{\prime}$ dimethylformamide, ethanol, iodine, potassium iodide, sodium acetate, sodium thiosulphate of pure grade were used in this investigation.

Dyestuffs: Some commercial cationic dyes were used such as C. I. Basic Blue 9 (C. I. Constitution No. 52015) quinone-imine; C. I. Basic Red 1 (C. I. Constitution No. 45160) xanthene; C. I. Basic Orange 2 (C. I. Constitution No. 11270) Azo; and C. I. Basic Violet 1 (C. I. Constitution No. 42535) phenyl-methane.

Pretreatment: Quiana polyamide substrate $(i \mathrm{~g})$ of known length and breadth were slack treated with occasional shaking with the ketone in proper solvent in a stoppered glass bottle at different temperatures for various time intervals using a liquor ratio of $1: 25$. The liquor was then sucked, the samples were thoroughly washed with running water. Drying of the washed samples was then performed at room temperature.

Shrinkage measurements:

The length and/or breadth of the samples were determined before and after treatment on at least 12 reproducible samples. The percentage shrinkage of the sample is represented by the following equation:

$$
\text { Shrinkage } \%=\frac{L_{\mathrm{o}}-L}{L_{\mathrm{o}}} \times 100
$$

$L_{\mathbf{0}}$ : Original length and $L$ : shrinked length

\section{Iodine sorption:}

$50 \mathrm{ml}$ of $1 \mathrm{~N}$ iodine solution were placed in stoppered flask in a thermostatic water bath at $70^{\circ} \mathrm{C}$ and $0.5 \mathrm{~g}$ of the substrate was introduced in the flask in the thermostatic water bath for 20 min. The samples were then withdrawn and sucked, washed with distilled water several times until the washings become colourless. The washed samples were then transferred in an Erlenmeyer flask containing $20 \mathrm{ml}$ of a 9:1 mixture of acetone/ water. The stoppered flasks were occasionally agitated at $50^{\circ} \mathrm{C}$ uptill complete desorption of iodine. The content of the flask was cooled, $10 \mathrm{ml}$ distilled water and $3 \mathrm{~g}$ KI were then added. Titration of the contained iodine was performed using standard thiosulphate solution $(0.01 \mathrm{~N})$.

Iodine sorption $=\frac{V \times 0.01 \mathrm{~N} \times E}{W} \mathrm{mg} \quad \mathrm{I}_{2} / \mathrm{g}$ fibres

$V$ : volume $(\mathrm{ml})$ of standard thiosulphate consumed

$W$ : Weight of the sample

$E$ : Equivalent weight of iodine.

\section{Dyeing technique:}

The substrate $(1 \mathrm{~g})$ was exhaust dyed in $100 \mathrm{ml}$ of a cationic dye solution at constant temperature and adjusted to $\mathrm{pH} 4$ with sodium acetate/acetic acid buffer system. A dyeing apparatus (Turbomat AHIBA, Switzerland) of circulating liquor system was used. The dyeing time, temperature, dye concentration as well as dye moiety were changed according to the prescribed experimental conditions.

\section{Dye extraction:}

The dyed substrates were completely extracted with hot $\mathrm{N}, \mathrm{N}^{\prime}$-dimethylformamide/water mixture $(1: 1)$ solution ${ }^{18)}$. The amount of extracted dye was determined spectrophotometrically.

\section{Colour measurements:}

Spectral reflectance measurements of the dyed polyamide fabrics was carried out using a recording filter spectrophotometer. The colour intensity expressed as $K / S$ values of the dyed samples was determined by applying Kubelka-Munk equation:

$$
K / S=\frac{(1-R)^{2}}{2 R}-\frac{\left(1-R_{0}\right)^{2}}{2 R_{0}}
$$

where $R$ is the decimal fraction of the reflectance of the dyed sample, $R_{0}$ is the decimal fraction of the reflectance of the undyed fabric. $K$ is the absorption coefficient and $S$ is the scattering coefficient ${ }^{19)}$.

Time of half dyeing $\left(t_{1 / 2}, \min \right)$ and specific dye rate constant $\left(K^{\prime}\right)$ :

Dyeing of polyamide fabrics was performed on a $5 \mathrm{~g}$ sample using $1 \%$ dye (on weight of fabric). Each set included dyeings for 5, 10,30,60 min and also for $12 \mathrm{hr}$. to establish equilibrium. Samples were removed from the dyebath immediately after the prescribed elapsed dyeing time. The remaining dye in the bath was determined spectrophotometrically. For each dyeing temperature, the percentage exhaustion versus dyeing time was plotted, $t_{1 / 2}(\min )$ was taken from the corre- 
sponding curve. The specific dye rate constant $\left(K^{\prime}\right)$ was calculated from ${ }^{20)}$ :

$$
K^{\prime}=0.5 C_{\infty}\left(d \cdot t_{H_{2}}\right)^{1 / 2}
$$

where $C_{\infty}$ is the percentage dye absorbed on the sample at equilibrium conditions between the sample and the dyebath divided by the weight of the sample, and $d$ is the fiber diameter in $\mathrm{cm}$.

\section{Apparent diffusion coefficient:}

A small weight of the sample $(0.1 \mathrm{~g})$ was dyed in a large volume of the dye solution $(80 \mathrm{ml})$ for a prolonged time (about $12 \mathrm{hr}$ ). The amount of dye taken up by the sample was completely extracted with dimethylformamide/water (1:1) mixture. The concentration of the dye in the fibres $C_{\infty}$ was then determined spectrophotometrically. Another dyeing was then carried out for a much shorter time $\left(10 \mathrm{~min}\right.$. and $C_{\mathrm{t}}$ was similarly determined. The value of $C_{t} / C_{\infty}$ was then calculated from which the diffusion coefficient $(D)$ could be calculated based on Hill's equation ${ }^{21)}$ :

$$
D=C_{\mathrm{t}} / C_{\infty} \cdot \frac{d^{2} \times 100}{t} \mathrm{~cm}^{2} \cdot \mathrm{sec}^{-1}
$$

\section{Affinity $\left(\Delta \mu^{\circ}\right)$ and heat of dyeing $\left(\Delta H^{\circ}\right)$ :}

A $5 \%$ dyeing (on weight of fabric) was performed on two $0.5 \mathrm{~g}$ samples at $80^{\circ} \mathrm{C}$ for $2 \mathrm{hr}$ using a liquor ratio $80: 1$. At the end of the dyeing time, the samples were immediately removed, rinsed in several changes of cold distilled water ${ }^{21)}$. One of the dyed samples was treated with $80 \mathrm{ml}$ of distilled water in a stoppered flask for $2 \mathrm{hr}$ at $80^{\circ} \mathrm{C}$. The other one was similarly treated for $4 \mathrm{hr}$ at $60^{\circ} \mathrm{C}$. At the end of the prescribed time, the samples were removed, rinsed for several times with distilled water and air dried. The amount of the dye in the desorption solution as well as the remaining part on the treated samples, were determined spectrophotometrically. Calculation of $\Delta \mu^{\circ}$ and $\Delta H^{\circ}$ were carried out by first calculating the partition coefficient of the dye $(K)$.

$$
\begin{aligned}
& K=\frac{\text { concn. of dye in fibre }(\mathrm{mg} / \mathrm{Kg} \text { fibres })}{\text { concn. of dye in solution }(\mathrm{mg} / \mathrm{L})} \\
& -\Delta \mu^{\circ}=2.3 R T \log K\left(\mathrm{cal} \cdot \mathrm{mol}^{-1}\right) \\
& \Delta H^{\circ}=\left[\frac{\Delta \mu_{1}^{\circ}}{T_{1}}-\frac{\Delta \mu_{2}^{\circ}}{T_{2}}\right] /\left[\frac{1}{T_{1}}-\frac{1}{T_{2}}\right]
\end{aligned}
$$

\section{Results and Discussion}

A thorough study was carried out on Quiana polyamide (Q-PA) fabric treatment with some ketones to induce some structural changes which would be reflected on improving fibre dyeability. It was generally seen that the treatment had revealed changes of fabric dimension as well as some tendency to fibre plasticization.

\section{Isothermal shrinkage:}

QPA fabric was treated with some ketones vis. acetone, 2-butanone, 3-pentanone, cyclohexanone and acetophenone at constant temperatures for various time intervals in alcoholic/water solutions (1:2). Changes in fabric dimensions was recorded and calculated either as length \% contraction and/ or area \% shrinkage. Fig. 1 presents isothermal shrinkage rate curves of Q-PA fabric treated with various ketonic solvents. It can be observed that the shrinkage rate curves are characterized by three stages. The first part is associated with an induction period which may reflect the diffusion behaviour of the ketonic solvents into the polymer structure and is naturally time dependent. The

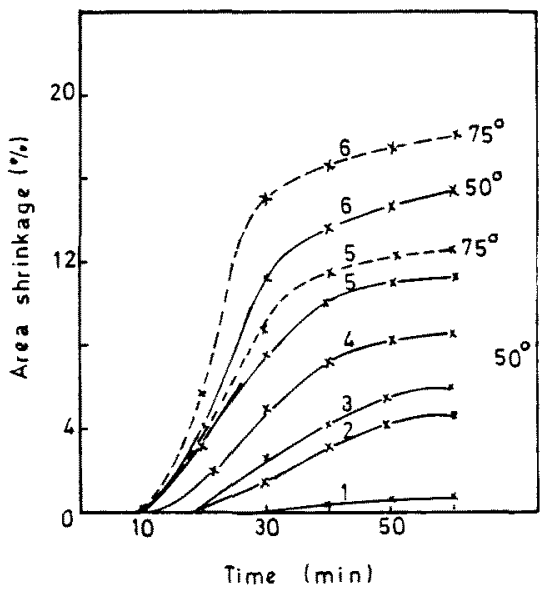

Fig. 1 Percentage changes in area shrinkage of Q-PA substrates treated at various temperatures with ketone/solvents for various times (liq. ratio 1:25).

$-50^{\circ} \mathrm{C} ;---75^{\circ} \mathrm{C}$

1) Control (ethanol/water) (1:2)

2) Acetone/ethanol/water $(1: 1: 2)$

3) 2-Butanone/ethanol/water $(1: 1: 2)$

4) 3-Pentanone/ethanol/water $(1: 1: 2)$

5) Cyclohexanone/ethanol/water $(1: 1: 2)$

6) Acetophenone/ethanol/water $(1: 1: 2)$. 
shrinkage rate achieved a maximuni. In the last stage, the rate of shrinkage decreased relatively to a nearly steady state, where further prolonging of fibre-ketone contact time did not enhance significantly the studied property. It is also worthy to state that these three characterized stages were temperature dependent. The shrinkage was found to be a thermally activated process where Arrhenius equation can hold good.

Assuming that the induction period of the shrinkage process is a matter of lag of diffusion of ketones into the Q-PA substrate, an activation energy of diffusion could be estimated. Table I presents the calculated activation energy of diffusion $(\Delta E \mathrm{KJ} / \mathrm{mole})$ as well as the corresponding molecular volume of the ketone/solvents mixture. It appeared that the molecular volume of the interacting solvents had influenced the corresponding energy of diffusion, meanwhile deformation and plasticization of substrate might occur simultaneously.

Table I Activation energy of diffusion $(\Delta E)$ of ketones/ethanol/water mixture $(1: 1: 2)$ in Q-PA substrate (based on temperature dependence of induction period).

\begin{tabular}{lcc}
\hline $\begin{array}{c}\text { Ketone } \\
\text { component }\end{array}$ & $\begin{array}{c}\text { Molecular } \\
\text { volume } \\
\mathrm{cm}^{3} \cdot \mathrm{mol}^{-1}\end{array}$ & $\begin{array}{c}A E \\
\mathrm{KJ} \cdot \mathrm{mol}^{-1}\end{array}$ \\
\hline Acetone & 31.46 & 37.52 \\
2-Butanone & 50.82 & 60.63 \\
3-Pentanone & 55.44 & 66.14 \\
Cyclohexanone & 57.35 & 66.20 \\
Acetophenone & 60.68 & 71.50 \\
\hline
\end{tabular}

Fig. 2 presents a correlation between the activation energy of shrinkage of Q-PA $(\Delta E)$ versus the resultant molecular volume of the mixed solvent. The higher $\Delta E$ appeared to be engaged with larger molecular species which would tend to form solvated polymer segments of greater effective volume. The difference in $\Delta E$ among the various ketone/solvent mixtures may be associated with some differences in the binding capacity of the solvent with Q-PA substrate. Ribnick et al. ${ }^{22}$ ) have concluded that shrinkage of synthetic fibres due to solvent attack is a complex process including contribution from diffusion, relaxation, crystallization and time, energy dependent molecular mechanisms.

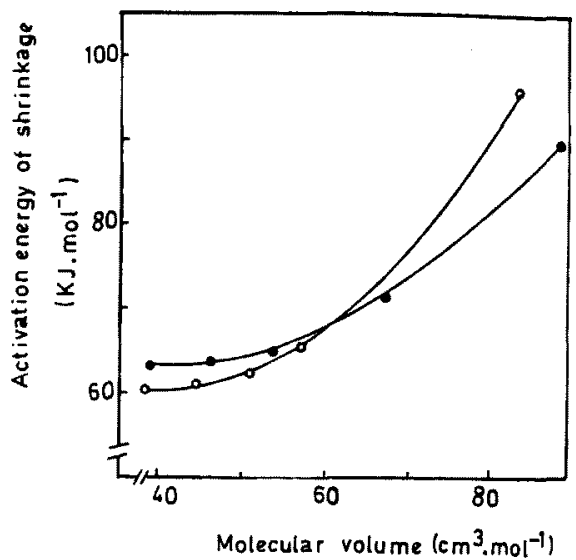

Fig. 2 Activation energy of shrinkage of Q-PA substrates versus the resultant molecular volume of different properties of ketones to ethanol/water $(1: 2)$ solvent, (liq. ratio $1: 25$ ).

Acetophenone;-O- Cyclohexanone:- -

\section{Dynamic shrinkage:}

Q-PA yarns were treated with a binary solvent mixture consisted of acetophenone/Cyclohexanone (1:1) at a heating rate of $2^{\circ} \mathrm{C} / \mathrm{min}$ up to $75^{\circ} \mathrm{C}$. Length shrinkage for at least 20 reproducible measured samples were recorded successively. Fig. 3 shows a starting diffusion controlled delay interval which is similar to the induction period observed during isothermal shrinkage. The shrinkage has increased sharply with increasing tempera-

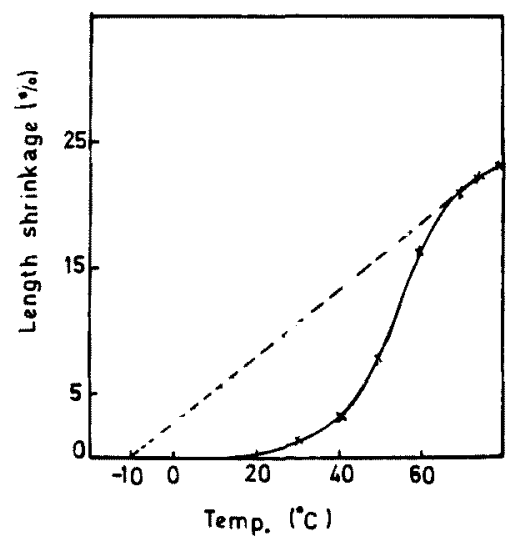

Fig. 3 Dynamic length shrinkage (\%) of Q-PA substrate in acetophenone/cyclohexanone (1:1) mixture at a heating rate of $2^{\circ} \mathrm{C} / \mathrm{min}$ (liq. ratio $1: 25$ ). 
ture upto about $50-60^{\circ} \mathrm{C}$, above which the temperature dependence of the shrinkage had decreased considerably. Extrapolating this last trend of slowed down shrinkage rate to intersect the temperature axis indicated the temperature at which zero-shrinkage occur $\left(T_{0}\right)$. The difference between the glass transition temperature $T_{\mathrm{g}}$ of Q-PA fibres and the recorded $T_{0}$ may give an indication of the extent of lowering $T_{\mathrm{g}}$ of the substrate due to solvent interactions.

\section{lodine sorption:}

Measurement of the sorption of iodine allowed the study of the variation of the free volume of Q-PA substrate submitted to acetophenone treatments. It allows to detect structural differences induced by variation of temperature of treatment. It was found that the acetophenone/cyclohexanone (1:1) treatment had decreased the iodine sorption by $24 \%$ at $50^{\circ} \mathrm{C}$ in relation to the corresponding value of iodine sorption of the untreated Q-PA substrate. Fig. 4 shows the effect of temperature of treatment on the relative decrease in iodine sorption of the treated substrate. It can be seen that the tendency of the modified substrate weakened with increasing the temperature up to $55^{\circ} \mathrm{C}$. This may be attributed to the higher influence of the solvent to plasticise and solvate the substrate. Iodine sorption capability of the substrate can be used as an index for the tendency of the polymer to crystallize. The effect of plasticising of acetophenone/cyclohexanone (1:1)

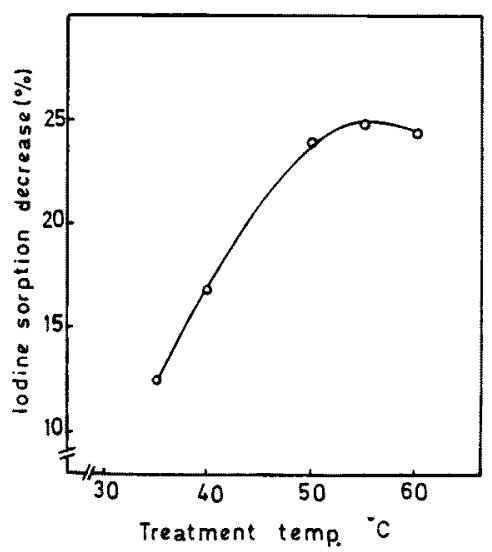

Fig. 4 Effect of temperature of pretreatment of Q-PA with acetophenone/cyclohexanone $(1: 1)$ on its iodine sorption capability (time $1 / 2 \mathrm{hr}$, liq. ratio $1: 25$ ). mixture on Q-PA is presumably to increase the degree of crystallinity. This effect might occur by reducing the forces of entanglement points between the macromolecular chains. Chain segments thereby acquired relatively sufficient free movement into a crystal arrangement. Part of the amorphous region remains in intact and tends slowly to crystallize at an extremely slow rate. The solvent molecules were expelled from the crystal, but still persist to influence the amorphous portion, which exhibited some mobility ${ }^{23,24)}$.

\section{Dye uptake:}

Changes in the capability of the modified Q-PA to uptake cationic dyestuffs were also noticed. Q-PA structural modification due to interaction with acetophenone/ethanol/water $(1: 1: 2)$ mixture showed some improvement in the accessibility of the substrate to cationic dyeing. Control samples showed no affinity to cationic dyes. This may conceivably ascribed to the modification of the diffusion capability and equilibrium dye-uptake as a result of the change in the Q-PA fine structure which is also presumably due to a shift in its glass transition temperature ${ }^{5,25-28)}$.

Fig. 5 illustrates the dependence of the colour intensity of the dyed Q-PA samples as expressed by $K / S$ values, on the time of pretreatment with

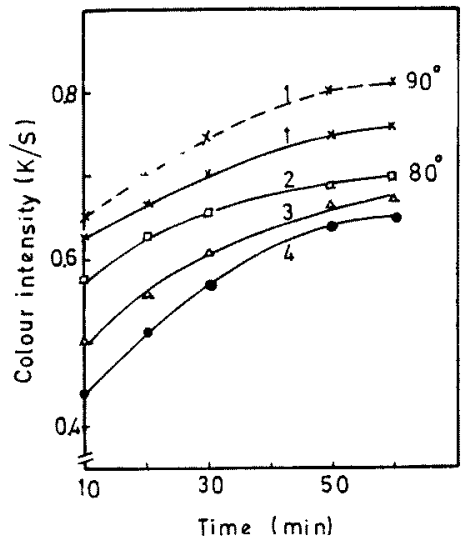

Fig. 5 Effect of time of pretreatment of Q-PA with acetophenone/ethanol/water mixture $(1: 1: 2)$ and dyeing temperature on the imparted colour intensity. (pretreat.: $70^{\circ} \mathrm{C}, 30 \mathrm{~min}$, liq. ratio $1: 25$ ). dyeing: dye $3 \%$ (on weight of fabric), $\mathrm{pH} 4$, liq. ratio $1: 100 ;-80^{\circ} \mathrm{C} ;---90^{\circ} \mathrm{C}$
1) Basic Blue 9
2) Basic Orange 2
3) Basic Red 1
4) Basic Violet 1 
acetophenone/ethanol/water $(1: 1: 2)$ at $70^{\circ} \mathrm{C}$. Dyeing was carried out at various temperatures for $1 \mathrm{hr}$ using a $3 \%$ shade of the cationic dyes. It is seen that levelling off of the mentioned property was given after about 45-60 min for the modified substrate.

\section{Kinetic evaluations:}

a) Time of half-dyeing: Q-PA substrates pretreated at $70^{\circ} \mathrm{C}$ for $45 \mathrm{~min}$ with acetophenone/ ethanol/water $(1: 1: 2)$ mixture were dyed under the same conditions with four cationic dyes of different basic structures, at $85^{\circ} \mathrm{C}$. The modified substrates were dyed fast, deep, level shade. Table II presents data of time of half dyeing $\left(t_{1 / 2}\right)$ as well as the corresponding specific dye rate constant $\left(K^{\prime}\right)$ of the modified substrate. Determination of $t_{1 / 2}$ provided an indirect measure of the diffusion rate of dyes into substrates. It seems to be a useful element for comparing the behaviour of the cationic dyes applied under identical conditions. This indicates that the pretreatment has a more powerful influence in disordering the polymer structure. Consequently, the dye-uptake characteristics were also modified. Generally, with regard to the dye molecule, it was noticed that with C. I. Basic Blue 9, $t_{1 / 2}$ value was the lowest which reflects the influence of dye molecule size, shape, volume on its mobilization and rapid uptake by the substrate. This was also confirmed elsewhere ${ }^{29,30)}$.

Table II Time of half dyeing $\left(t_{1 / 2}, \min \right)$ and specific dye rate constant $\left(K^{\prime}\right)$ of modified Q-PA substrate dyed with various cationic dyes.

\begin{tabular}{lcc}
\hline \multicolumn{1}{c}{ Dyestuffs } & $t_{1 / 2}, \min$ & $K^{\prime}$ \\
\hline Basic Blue 9 & 12 & 0.124 \\
Basic Red 1 & 14 & 0.132 \\
Basic Orange 2 & 16 & 0.146 \\
Basic Violet 1 & 20 & 0.153 \\
\hline
\end{tabular}

Dyeing: dye $2 \%$ (on weight of fabric), liq. ratio $1: 100, \mathrm{pH} 4,85^{\circ} \mathrm{C}$.

Pretreatment: Acetophenone/ethanol/water $(1: 1: 2)$, $70^{\circ} \mathrm{C}$, liq. ratio $1: 25$.

b) Diffusion coefficient: The apparent diffusion coefficient $(D)$ of cationic dyes into modified Q-PA substrate was determined by performing a dyeing process from an infinite dyebath and supposing that the fibres have approximately circular cross-sections. $D$ values were calculated
Table III Apparent diffusion coefficient of Basic dyes in dyed modified Q-PA substrates.

\begin{tabular}{lcc}
\hline Dyestuffs & \multicolumn{2}{c}{$\begin{array}{c}\text { Apparent Diffusion Coefficient } \\
\mathrm{cm}^{2} \cdot \mathrm{sec}^{-1}\end{array}$} \\
& at $60^{\circ} \mathrm{C}$ & at $90^{\circ} \mathrm{C}$ \\
\hline Basic Blue 9 & $4.182 \times 10^{-10}$ & $4.216 \times 10^{-10}$ \\
Basic Red 1 & $4.026 \times 10^{-10}$ & $4.067 \times 10^{-10}$ \\
Basic Orange 2 & $3.981 \times 10^{-10}$ & $4.022 \times 10^{-10}$ \\
Basic Violet 1 & $3.622 \times 10^{-10}$ & $3.832 \times 10^{-10}$ \\
\hline
\end{tabular}

Dyeing: dye $3 \%$ (on weight of fabric), liq. ratio $1: 100$, pH 4.

Pretreatment: Acetophenone/ethanol/water (1:1:2), $70^{\circ} \mathrm{C}$, liq. ratio $1: 25$.

according to Hill's equation ${ }^{21)}$. The magnitude of $(D)$ for the studied cationic dyes in the modified substrate in depicted in Table III. This capability has been considered to arise from dye by virtue of the strong adsorption forces between the dye and substrate and from the resistance to motion offered by the substrate macromolecule matrix ${ }^{2)}$. It was also observed that the rate of diffusion of the dye in the fibres has increased with rise of dyeing temperature. The effect of temperature can be also exemplified numerically by calculating the apparent activation energy of diffusion $\left(E_{\mathrm{D}}\right)$ from the Arrhenius law:

$2.3 \log E_{\mathrm{D}}=-E / R T=$ constant

$E_{\mathrm{D}}$ can be considered to be a reflection of the way in which diffusion coefficient changes with dyeing temperature. It may be also regarded as the energy which the dye molecule might acquire in order to be able to move within the fibre matrix. $E_{\mathrm{D}}$ was found to be 72 and $88 \mathrm{KJ} \cdot \mathrm{mol}^{-1}$ for C. I. Basic Blue 9 and Basic Orange 2 respectively.

c) Affinity and heat of dyeing:

Dyeing of the modified substrate with $5 \% \mathrm{C}$. I. Basic Blue 9 (on weight of fabric) at $80^{\circ} \mathrm{C}$ was allowed to proceed to a practically true equilibrium so that the fibres were completely and uniformly penetrated by the dye molecules and their adsorption and desorption would take place at the same rate. By determining the partition coefficient $(K)$, i.e. the ratio of the concentration of the dye on the fibres to that in the bath, the affinity $\left(-\Delta \mu^{\circ}\right)$ at various temperatures, the heat of dyeing $\left(\Delta H^{\circ}\right.$ ) could be therefrom calculated ${ }^{2)}$.

It was seen that $\Delta \mu^{\circ}$ and $\Delta H^{\circ}$ were negative values indicating that the dyeing process is an 
exothermic process. The increase in the dyeing temperature had decreased the $K$ values as well as the affinity of the dye to the fibres. Pretreated substrate had acquired $-\Delta \mu^{\circ}$ values of 14.7 and $21.3 \mathrm{KJ} \cdot \mathrm{mol}^{-1}$ at $60^{\circ}$ and $75^{\circ} \mathrm{C}$ respectively. The measured heat of dyeing $\left(\Delta H^{\circ}\right)$ was in the order of $33.6 \mathrm{KJ} \cdot \mathrm{mol}^{-1}$ This was anticipated since more disorder in the fine structure of the pretreated substrate was imparted which makes it more accessible to dyeing. The increase in accessibility could be also traced from the comparison of the affinity values, since the differences in the amount of crystalline or other region inaccessible to dye molecules in the fibre structure might cause variations in the dye-uptake.

\section{References:}

1) I. D. Rattee and M. M. Breuer, "The Physical Chemistry of Dye adsorption", Academic Press, London, New York, 1974.

2) R. H. Peters, "Textile Chemistry, III - The Physical Chemistry of Dyeing", Elsevier, London, 1975.

3) C. H. Giles, "The Theory of Colouration of Textiles", The Dyers Co. Publications Trust Bradford, England 1975.

4) T. Oda, K. Oh and A. Shima, Jap. Pat. 7223689; 7223690 (1972); Chem. Abstr. 78, 31343d, 31344e (1973).

5) A. Bendak and H. L. Hanna, Teintex, 44, 11 (1979).

6) Hoechst, A.-G., Brit. Pat. 1242756 (1971); Chem. Abstr. 75, 141913p (1971).

7) F.F. Bartsch, USPat. 3836327 (1974); Chem. Abstr. 82, 74350d (1975).

8) Y. Taneda, K. Naka and Y. Horiya, Jap. Pat. 7223,989 (1972); Chem. Abstr., 77, 166063 (1972).

9) A. Bendak, Textiverdlung, 14, 526 (1979).

10) A. Bendak, F. I. Abd El-Hay and V. Metri, Bull. Nat. Res. Centre, Egypt, 4, 307 (1979).

11) T. Shibano, K. Kawakami and H. Imagome, Jap. Pat. 75145675 (1975); Chem. Abstr., $84,61080 \mathrm{~g}(1976)$.
12) K. Joko, Osaka-furitsu Sen'i Gijutsu Kenkyusho Hokoku, 17, 44 (1984); Chem. Abstr., $102,186560 \mathrm{k}(1985)$.

13) S. Kuwabara and T. Shirota, Jap. Pat. 7306429 (1973); Chem. Abstr., 80,134772p (1974).

14) I. Spers, US Pat. 3674420 (1972); Chem. Abstr., 77, 103216 (1972).

15) M. Scheller, Brit. Pat, 1246757 (1971); Chem. Abstr., 76, 26352k (1972).

16) J. Economy and G. Y. Lei, US Pat. 3993442 (1976); Chem. Abstr. 86, 30961g (1977).

17) M. Kurokawa, T. Konishi and Y. Tansei, Bull. of the Inst. Chem. Res. Kyoto Univ., 55, 189 (1977).

18) E. Kissa, Text. Res. J., 45, 488 (1975).

19) D. Judd and G. Wyszecki, "Colour in Business, Science and Industry", John Wiley \& Sons, New York, 1975.

20) K. Johnson, "Dyeing of Synthetic Fibres, Recent Development", Noyes Data Corp., New Jersey, London, 1874.

21) C. H. Giles, A. Datyner, D. G. Duff, R. S. Sinclair, and C. B. Stens, "A Laboratory Course in Dyeing", Soc. Dyers Color., 3rd Ed., Bradford, Yorkshire, 1974.

22) A. S. Ribnick, H. D. Weigmann and L. Rebenfeld, Text. Res. J., 43, 176 (1973).

23) A. S. Ribnick and H. D. Weigmann, Text. Res. J., 43, 316 (1973).

24) A. Bendak, and L. A. Abdou, Kolor. Ert., 21, 165 (1979).

25) T. Wakida, T. Takagishi and A. Katayama and N. Kuroki, Sen-i Gakkaishi, 32, T 172 (1976); Chem. Abstr., 85, 34512p (1976).

26) T. Hirose, E. Koga, T. Sugimoto and $S$. Kamazawa, Pap. Pat., 7684981 (1976); Chem. Abstr., 85, 161808q (1976).

27) H. D. Weigmann, A. S. Ribnick, Text. Solvent Technol. Update 73 AATCC Symp., p.24 (1973).

28) D. R. Buchanan, and J. P. Walters, Text. Res. J., 47, 398 (1977).

29) O. Glenz, W. Beckmann and W. Wunder, $J$. Soc. Dyers Col., 75, 141 (1959).

30) J. Crank, and G. S. Park, "Diffusion in Polymers", Academic Press, London, New York, 1968. 
キアナーポリアミド緎維におけるケトン類の作用

National Research Centre, Textile Research Division Dokki, Cairo, EGYPT A. Bendak

Faculty of Engineering, Cairo University

Sh. Aggour

キアナーポリアミド䋐維 (Q⿱中一㇀ $-\mathrm{PA})$ のケトン類による 前処理は，瀻維構造の変化を引き起こし，その繊維の染 色性を改良する。改質Q-PAの等温収縮率は，浴剤によ る処理時間と温度に依存する。相互作用するケトン類/ 溶剂の分子容は，高分子中の拡散の活性化エネルギー $(A E)$ に影響し，ケトン類／溶剂間の $\Delta E$ の差は，基質 しの結合容量の差と関連づりらる。動収樎率は，前処 理温度の上昇と共に鋭く增大する。改質 $\mathrm{Q}-\mathrm{PAKよる}$ ヨウ素の収着は，誘起した構造変化の差を検知すること
によって測定される。

改質Q-PAのカチオン染料収着におりる半染色時間お よび染色速度定数の比は, 前処理による瀻維の構造変化 に強く影響される。改翼Q-PA中の染料の拡散速度は, 染色温度の上昇之共に増大する。み加りの抬散の活性化 エネルギーは，繊維マトリックス内の染料分子の運動性 を示唆し，染料の親和力および染色熱は，前処理による

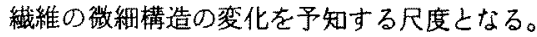

